\title{
Building the Nigerian Statistical System Capacity for Poverty Reduction and Sustainable Development in the New Millennium
}

\author{
Hamadu, Dallah \\ Department of Actuarial Science and Insurance, University of Lagos, Akoka, Lagos, Nigeria \\ Email: dallaram2007@yahoo.com,dhamadou@unilag.edu.ng \\ Okafor, Ray \\ Department of Mathematics, University of Lagos, Akoka, Lagos, Nigeria \\ Email: okaforray@yahoo.com \\ Oghojafor, Ben \\ Department of Business Administration, University of Lagos, Akoka, Lagos, Nigeria \\ Email: okpoyomareo@yahoo.com
}

Accepted: October 03, 2012 Published: October 27, 2012

Doi:10.5296/jsr.v3i2.2567ＵRL: http://dx.doi.org/10.5296/jsr.v3i2.2567

\begin{abstract}
Reducing poverty in developing countries like Nigeria fundamentally depends on the efforts of government at all levels, especially in carrying out the implementation of institutional reforms needed to improve economic performance and evidence-based policy decision process necessary for jobs creation, social services delivery and improvement of quality of life. After examining the state of Nigerian Statistical System (NSS) and the challenges its faces in the provision of timely, and reliable information for poverty reduction strategies and other developmental indicators required for monitoring and evaluating progress, we recommend the development of grassroots statistics, data collection methodology and group support system (GSS) to monitor and evaluate performance of poverty reduction and crucial developmental programmes. Finally, the implementation of the paradigm will contribute towards the achievement of Millennium Development Goals (MDGs).
\end{abstract}

Keywords: Poverty Reduction, NSS, MDGs, Grassroots Statistics, Data Collection Methodology, GSS.

\section{Introduction}

Development planning for poverty reduction and sustainable growth in Nigeria 
fundamentally depends substantially on the efforts of government at all levels, especially in carrying out the implementation of reforms needed to improve economic performance and strategic policies needed for jobs creation and empowerment of women and the vulnerable. The Millennium Development Goals (MDGs) ambitious targets (Vision 2015) for poverty reduction have been well publicized by both states and Federal governments. Fortunately, one the benefits of the MDGs is to focus attention on key outcomes of government strategic activities, which then provide a basis for prioritizing institutional capacity building activities. In Nigeria, the process of building statistical capacity has a short history, some 50 years or so, but, recently the nation has been involved in several national, regional and continental initiatives for building capacity through the national strategy for development of statistics (NSDS). The most popular are Addis Ababa Plan of Action for Statistical Development in Africa in the 1990s (AAPA) and Partnership in Statistics for Development in the $21^{\text {st }}$ Century (PARIS21) (Hamadu and Okafor, 2009, and Kiregyera, 2001).Thus, building statistical capacity to be able to collect and disseminate statistical information needed for effective and efficient policy implementation and to do so, in line with internationally acceptable standards is crucial for poverty reduction and sustainable development. This paper examines the usefulness of building the statistical institutional capacity for proper monitoring and evaluation of Poverty Reduction Strategies (PRPs) and sustainable growth and development. Furthermore, we recommend the development of data collection, dissemination, mining and decision support system to strengthen the Nigerian Statistical System. The remainder of this paper is organized as follows: In Section 2 we present poverty reduction and sustainable development strategies, and the statement of problems are given in Section 3. The objectives of building Nigerian statistical capacity is given in Section 4 and Section 5 present a critic of Nigerian statistical system. In Section 6, we give a few recommendations with special attention to grassroots statistics and data collection and dissemination methodology. Section 7 present the appropriate decision support system (GSS) to strengthen the multi-sectoral needs and coordination of the system.

\section{Poverty Reduction and Sustainable Development Strategies}

Poverty is a chronic or temporary state of relative or absolute destitution that affects some social groups. This destitution may manifest itself through several economic and social dimensions:

i. Income poverty: that is inadequate resources for a minimal level of consumption;

ii. Food and economic insecurity and extreme vulnerability to natural disasters and economic crises;

iii. Lack of or limited access to essential social services 9 health, education, ect.); and

iv. Social insecurity: vulnerability to bad governance and to conflicts.

Hence, poverty reduction and sustainable development require a lot of information for decision making. How many people are literate? How many children are vaccinated? What is the prevalence rate of HIV/AIDS in the country? How many people are self employed? Is the employment level improving? Getting such crucial information in a timely, regular and 
reliable manner, however, has been a challenge in Nigeria. Several strategic frameworks for development have been initiated amongst others are the Millennium Development Goals (MDGs), and the homegrown National Economic Empowerment and Development Strategy (NEEDS) and the current sitting government Seven-Point Agenda.

\subsection{The Millennium Development Goals (MDGs)}

The millennium development goals (MDGs) were signed in September 2000 by leaders of nearly all members of the United Nations (UN) and some international organisations and civil society groups. The goals represent eight broad benchmarks for global development, ranging from eradication of extreme poverty and hunger to promotion of gender equality and empowerment of women, achievement of universal primary education, reduction of child mortality and improvement of maternal health, combating of HIV/AIDS, malaria and other diseases, and promotion of environmental sustainability and global partnership for development (UN, 2006). Each MDG also includes a number of indicators designed to measure its progress, and they (indicators) are intended to be backed and updated regularly by the UN member governments and international bodies such as the World Bank (WB), International Monetary Fund (IMF) and continental bodies like the African Union (AU) and our regional body the Economic Commission of West African States (ECOWAS). The timeline for achievement of the MDGs is 2015. This deadline, of course, throws a challenge to countries like Nigeria, that seem to have fallen behind meeting key targets, to improve institutions that promote statistical capacity building that will in turn inform national development planning processes (Hamadu and okafor 2009).

\subsection{National Economic Empowerment and Development Strategy (NEEDS)}

This is the home-grown Nigerian Poverty Reduction Strategy Papers (PRSPs). It is a plan for prosperity which allows government to know what kind of Nigeria its citizens want to live in now and in the future.

Realising that, although, Nigeria is a rich nation in natural and human resources, about $70 \%$ of Nigerians live on less than $\$ 1$ a day. NEEDS document intend to make poverty a thing of the past in Nigeria. It aims to create a Nigeria that Nigerians can be proud to belong to and grateful to inhabit, a Nigeria that rewards hard work, protects its people and their property, and offer its children better prospects than those they may be tempted to seek in Europe or the United States (NEEDS 2005).

In the quest of realising the above vision, NEEDS focuses on four key strategies:

1. Reorienting values,

2. Reducing poverty,

3. Creating wealth, and

4. Generating employment

More importantly, NEEDS is a development plan that integrates economic development 
efforts at the federal, state, and local government levels. Moreover, the document also recognises that the national statistical system is weak and absolate. Therefore, a new master plan for the NSS is being initiated as earlier as 2005. Hamadu and Okafor $(2008 ; 2009)$ have given a blue-print of how to achieve this, so that most of the NEEDS programmes at all levels of governments can integrated, monitored, evaluated and controlled.

\subsection{The Seven-Point Agenda}

Besides the MDGs, and the home-grown NEEDS, the current administration has its own development agenda called "the seven-point agenda" by the present Nigerian administration. The agenda is government's blueprint for development in critical sectors such as energy and power, education, health, infrastructure, national security, rule of law, and resolution of Niger Delta problem. The president has emphasized that "our seven point agenda is aimed at a structured approach to tackling challenges which we must overcome if we are to raise the living standards of Nigerians, achieve the MDGs and realize our Vision 2020." The latter is Nigeria's dream to be in the league of the twenty leading economies of the world by the year 2020.

\section{Statement of Problems}

From the look of things, at present the Nigerian government does not have the enabling tools to work, especially reliable and timely data it needs to plan take proactive decisions and execute its programmes. It is well-known to many Nigerians and even foreigners that there are serious statistical data deficits pervading almost the entire political-cum-socio-economic landscape. Suffice it to cite a few examples:

(i) Post-independence national censuses in Nigeria have mostly been controversial and their gazetted figures are still being challenges by many states and local governments alike.

(ii) Data on vital registrations, as a corollary to census data, are not fairing any better.

(iii) Critical health statistics in Nigeria are grossly unreliable. For example, there has never been any national survey on maternal mortality in this country yet about $10 \%$ of global maternal deaths is routinely attributed to Nigeria. There is also frequent argument about the conflicting HIV/AIDS prevalence rates (a key MDGs indicators) emanating from several government and other agencies.

(iv) The rates of implementation of national budgets by the executive arm of the federal government are perennially disputed by the national assembly.

(v) Non conduct of regular surveys (Households Survey, Health and Demographic Survey, Employment Survey etc...)

(v) We can go on and on, to cover data deficits in other strategic sectors such as data on 
education, employment, agriculture and environment.

\section{Objectives of Statistical Capacity Building}

The main objective is to transform the Nigerian Statistical System (NSS) for improved and sustainable performance and coordination. Against this back drop we adopt the following broadly-based objectives of building statistical capacity in Nigeria (Kiregyra, 2001; Hamadu and Okafor 2009) as:

- achieve national self-sufficiency in statistical production, including the creation of a comprehensive national database;

- $\quad$ improve the reliability and relevance of data produced in Nigeria;

- undertake production of data required for formulating and evaluating programmes designed to restructure and transform the Nigerian economy;

- improve the timeliness in the production and dissemination of statistical information;

- increase awareness of the importance of statistical information among users;

- strengthen and sustain training programmes at various levels and institutions;

- encourage improvement in the organisational set-up of the NSS;

- improve coordination of all statistical development programmes at federal, state and local areas levels;

- lobby for the speedy passage of the Freedom of Information Legislation by the national assembly;

- foster cooperation and ultimate integration of the statistical systems of member countries of the Economic Commission of West African States ( ECOWAS);

- provide new strategic directions for statistical development in Nigeria, taking into account new challenges as well as opportunities created by the realized need among development partners for increased coordination and collaboration, and advances in statistical analysis and Information and Communication Technology (ICT) infrastructures.

\section{Critic of Nigerian Statistical System}

\subsection{Nigerian Statistical System (NSS)}

The Nigerian Statistical System is comprised of two main statistical/population agencies of the Federal Government of Nigeria (FGN), namely, the National Bureau of Statistics (NBS) and the National Population Commission (NPC).Besides these, there are several other (second-tier) agencies of the FGN, for example, ministerial, sectorial and departmental units which, because of the kinds of statutory functions they perform, generate data that are useful to the FGN for planning purposes. Institutions such as Central Bank of Nigeria (CBN) and Nigerian National Petroleum Corporation (NNPC) belong to the second tier group. 


\subsection{Challenges and Weakness Of NSS}

In assessing the adequacy and functionality, or otherwise, of the NSS, we need to factor in the fact that the Nigerian federation operates government at three levels, namely, federal, state, and local. Each tier of government makes its own annual budget and has a responsibility to deliver good governance to its constituents. Which means that reliable and timely data are required for planning and decision-making at each tier? So are the data needs of each tier of government being met? We try to answer, by taking the tiers one after another.

(i) Federal Level

The Nigerian Statistical System as presently organized cannot deliver on its mandate of furnishing the FGN with the data its needs for quality governance. This weakness can be considered from two perspectives

Non-performance of the FOS which initiated the new master plan for the NSS in tandem with the creation of NBS through the national strategies for the development statistics (NSDS).

The second perspective on the weakness of the NSS is about data collection, coordination and exchange among the data-producing agencies. There is virtually no coordination among the agencies.

(ii) State and Local Levels

Organized statistics at the State and Local government levels, that is statistics at the grassroots, are nonexistent. No state of the federation has any statistical body in the mould of the NBS.

\section{Development of Grassroots Statistics}

\subsection{Establishment of State Bureau of Statistics}

Presently, statistical activities at state level seem to be fragmented and largely uncoordinated. We advocate that each state government should establish its own State Bureau of Statistics (SBS) which ideally should be in the mould of the NBS. It will be established by enabling legislation enacted by the state legislature. Whilst the SBS would be the focal point of state statistical coordination and policy, its activities should be in tandem with national statistical coordination and standards as enshrined in the laws establishing the NBS. What the SBS is designed to be can be encapsulated in three broad themes, namely: mission statement, integrity and the challenges it will face both in short and long terms. 


\subsubsection{Mission Statement}

Basically, the SBS is to act as the sole data repository and statistical information agent of the state government. In other words, the SBS replicates at the state level what the NBS does at the national or federal level. In specific terms, the mission of each SBS is to create a state statistical or database system which would be comprised of local governments' databases, data from surveys periodically conducted by SBS and statistics compiled by various agencies of the state government and non-governmental organisations. The state database system should serve as both the kernel database and the hub of the entire statistical system. The database is the focal point, for generating useful information for decision-making at both local and state government levels, and ultimately integrating state statistics into the national database system (see Hamadu and Okafor 2009).

\subsubsection{Integrity of SBS}

We advocate that the policy makers in the executive branch of the state government, legislators, and the general public must have a high level of trust in government statistics as forming the factual basis for public policy. For this reason, the SBS must be impartial in its work and perceived by the public to be neutral on political debates about state goals and issues. That neutrality should be protected by broad accountability. Thus, the SBS should be sensitive to the state governor's direction as to programme priorities, responsive to the state assembly's oversight, and accountable to the general public and other users of state statistics. It should be sufficiently independent to overcome any threats to the integrity of state statistics, including possible efforts to politicise the manner in which statistical inquiries are formulated and data are gathered, analysed, published, or otherwise disseminated.

\subsubsection{Challenges}

It is important to note that, the greatest challenge to be faced by the SBSs and even the NBS is dearth of statistical and related personnel they need to execute their mandate. We are talking of dearth of manpower in both quality and quantity. Shortages of manpower, especially at the high-end and technical levels, pervade nearly all sectors of the Nigerian economy. So, shortages are bound to be more acute in technically-oriented state-level institutions. The point at issue is that Nigerian universities and other institutions of high learning presently lack the capacity to produce adequate numbers of high-level manpower, especially in science and engineering fields. Hamadu and Okafor (2009) have made useful recommendations to ameliorate this problem. Some of the suggestions are:

(i) conduct on regular basis, in-house training programmes, especially for junior and mid-level staff, using their senior and more experienced staff, 
(ii) institute well-designed staff development programmes whereby qualified staff are sponsored to proceed to universities for their undergraduate and/or postgraduate degrees, and encourage the exposure and participation of high-level and technical cadre to workshops, conferences and training programmes organised by the Nigerian Statistical Association (NSA), the International Statistical Institute (ISI) and other regional and international statistical organisations, and

(iii) seek technical assistance from international donors through the NBS. Indeed, establishment of an SBS is the type of sub-national statistical capacity building project that can qualify a national statistical agency such as NBS to access technical assistance from donor agencies. For example, the Trust Fund for Statistical Capacity Building (TFSCB) has been established by the Development Data Group of the World Bank to strengthen the capacity of statistical systems in developing countries. In particular,

TFSCB offers financial assistance to national statistical systems to initiate new statistical activities or projects.

As for other major challenges, such as funding constraints and inadequacies in infrastructures and equipment, it is our view that government, having wisely established SBS, will make adequate budgetary appropriation for the running and sustainability of the agency. The management of SBS, on its part, should lobby both the executive and legislative arms of government for needed funds to be appropriated.

\subsection{Data Collection and Dissemination Methodology}

\subsubsection{Data Collection and Dissemination Activities al WARD Level}

Naturally, statistical activities should commence at the ward level, the most important of which is the collection of data on critical socio-economic-cum-cultural fundamentals that define the quantum of social, cultural and business activities at the grassroots level. The most basic data to be collected at the ward level are data on registration of births, deaths, and other social functions and activities such as marriages.

Statistical activities at the ward level require an institutional framework. We advocate the establishment of a sub-office of the State Bureau of Statistics (SBS) in each ward. The sub-office should be manned by requisite statistical personnel from SBS. The primary duty to be performed in the sub-office is the production of ward-level data, which may include data on: vital registrations, prices of primary commodities in the local markets, school enrolments, primary health care delivery, employment, household structure, road and transport, important local events, etc. The strategies to be used in collecting these data may vary. For example, data on vital registrations can be collected by using well-designed forms and distributing copies of the forms to selected community leaders who will fill-in the data on events of 


\section{Al Macrothink}

Journal of Sociological Research

ISSN 1948-5468

2012, Vol. 3, No.2

interest as they happen. The completed forms are to be returned to the sub-office periodically (monthly, for example).

Other types of data such as data on prices and household structure can be produced through market research and/or sample surveys to be initiated and designed at the SBS headquarters. The entire data from the constituent wards are transmitted manually to the local government headquarters for processing.

Table 1: Prospective socio-economic-cum cultural for collection of statistical data at ward level.

Item

Description

\begin{tabular}{|l|l|}
\hline $\begin{array}{l}\text { Location, Area Town Villages and } \\
\text { People }\end{array}$ & $\begin{array}{l}\text { Administration and Physical boundaries } \\
\text { Ethnic groupings and Population } \\
\text { National Monument, Archives and Museums }\end{array}$ \\
\hline Ecology and Climatology & $\begin{array}{l}\text { Ecological data (erosion, subsidence flooding, } \\
\text { etc.) } \\
\text { Climatic and Weather data } \\
\text { Vegetation } \\
\text { Environmental Pollution }\end{array}$ \\
\hline Labour & $\begin{array}{l}\text { Level, type and distribution of available } \\
\text { manpower } \\
\text { Labour Mobility }\end{array}$ \\
\hline Commerce & $\begin{array}{l}\text { Main markets } \\
\text { Principal goods and commodities available } \\
\text { Mode of goods exchange good } \\
\text { Banking activities and Banks }\end{array}$ \\
\hline Industry & $\begin{array}{l}\text { Industries and their location } \\
\text { Classification of industries } \\
\text { Resources and raw materials and their sources } \\
\text { Federal or State presence }\end{array}$ \\
\hline Natural Resources & Schools and Colleges Tertiary' Institutions? \\
\hline Schools, Colleges & $\begin{array}{l}\text { Location } \\
\text { Whether Federal or State } \\
\text { Voluntary agencies? }\end{array}$ \\
\hline Institutions & Mineral Deposits: Types and Locations \\
\hline
\end{tabular}




\begin{tabular}{|c|c|}
\hline & Mining activities: Types and Locations. \\
\hline Health & $\begin{array}{l}\text { Type and number of health institutions } \\
\text { hospitals, clinics, maternity homes, health } \\
\text { centres, trado-medical centres } \\
\text { Number of health personnel } \\
\text { Average number of persons per house-hold } \\
\text { Birth and death indices } \\
\text { Maternal and Child Mortality } \\
\text { Common ailments and other health } \\
\text { peculiarities, HIV } \\
\text { Any Federal and State Health Institutions'? }\end{array}$ \\
\hline Roads and Transportation & $\begin{array}{l}\text { Location of mayor roads: Classification of } \\
\text { roads } \\
\text { State of major roads; level of } \\
\text { maintenance, major modes of } \\
\text { transportation } \\
\text { Effect of trade commerce }\end{array}$ \\
\hline $\begin{array}{l}\text { Information Communication } \\
\text { Network }\end{array}$ & $\begin{array}{l}\text { Radio/TV Stations, Telephone Facilities } \\
\text { Radio/TV sets per unit of population } \\
\text { Post Offices }\end{array}$ \\
\hline Water Supply & $\begin{array}{l}\text { Type of water supply system; natural, public } \\
\text { borehole, wells }\end{array}$ \\
\hline Electricity & $\begin{array}{l}\text { Type of Electricity supply available: rural, } \\
\text { national grid, personal generators, none at all, } \\
\text { consumption. }\end{array}$ \\
\hline Agriculture & $\begin{array}{l}\text { Nature of vegetation, and Climatic condition } \\
\text { Type of agricultural activities } \\
\text { Type of land holdings, Agricultural Inputs } \\
\text { Major food and cash crops } \\
\text { Availability of extension services and credit } \\
\text { facilities } \\
\text { Cooperative farming }\end{array}$ \\
\hline $\begin{array}{l}\text { Civil/Traditional } \\
\text { Institutions }\end{array}$ & $\begin{array}{l}\text { Main customs and taboos } \\
\text { Local festivities } \\
\text { Conduct of marriage, birth and death } \\
\text { ceremonies } \\
\text { Chieftaincy institutions and prominent chiefs } \\
\text { Main religions. }\end{array}$ \\
\hline
\end{tabular}

Source: Hamadu and Okafor (2009)

\subsubsection{Data Collection and Dissemination Activities al Local Government}




\section{MlMacrothink}

Establishment of a statistical unit in each LG headquarters is imperative. The council area database would be situated in this unit. The database should be a computerized system, which integrates related data from the constituent wards, and from other council organs. The unit is manned by adequate compliment of computing/statistics personnel and support staff. It is the duty of this unit to collate, code, and electronically process the data from the wards and other sources, and leave the result in a database form for easy updating, retrieval and usage by both the executive and legislative arms of the local government. All these activities described above should be performed in accordance with guidelines provided by the SBS.

\subsection{Routine National Surveys and Administrative Records}

For any meaningful sustainable development Nigeria must imbibe with culture of data collection and dissemination through proper records keeping, regular vital surveys and census.

\section{i. Population Census}

Population census contains basic information on all citizens of a Nation. The census is always carried out for all households to obtain basic information on the entire population, its demographic structure, and its location. The census is typically carried out by the national statistics office, which then provides data to lower levels of government tailored to local information needs. Since the census covers the whole population, it is costly, and most countries conduct a census only once per ten years. Nigeria as a nation has experienced serious problems in all the four censuses conducted by the NPC mostly due to human resources and expertise. Consequently, we advocate the complete integration of NPC into the NBS to strengthen the NSS. From the look of things, Nigeria is not ready for the well publicized continental Households Surveys in Africa even though several supports and advocacy have been undertaken by UNECA, WB, IMF, AfDB and PRAIRS21.

\section{ii. Administrative Data}

In most developing countries like Nigeria, administrative data are the most accessible data source. Usually provided by line ministries and specialized agencies, these data describe specific activities and programs such as school enrollment, disease prevalence, malnutrition information, hospital expenses, road network information, and income and expenditure for decentralized units. This information is important in assessing levels of public and private inputs, outputs, and outcomes, as well as their distribution within the country. Administrative data can often provide an important entry into poverty analysis, especially if it they are used to compare need and demand for services.

iii. Routine National Surveys 
The census can provide policymakers with important data for planning in the years directly following its implementation, but its usefulness diminishes after that, hence there is need to conduct regular surveys. The followings are the most predominantly used survey methodology in most successful nations.

\section{a. Household Surveys}

Household surveys are essential for the analysis at the household level. The census covers the whole population in the country, surveys interviews only a subset, generally a small fraction, of all households. This sample of households must be carefully chosen so that the results of the survey accurately describe living conditions in the country, and different parts of the country.

\section{b. Demographic and Health Surveys}

These are special household surveys geared to exploring the incidence of diseases and use of health facilities usually conducted by the NSO or/and the Ministry of Health. They collect anthropometric data - height, weight, and age of children, that can be used to calculate malnutrition rates--and many other health and health behavior-related variables that enable such factors as survival rates, birth histories, birth intervals, and disease incidences and prevalence to be computed. The surveys also contain basic data about housing conditions, educational attainments, employment patterns, and sometimes household assets. The conduct of this survey is very useful for the generation of information needed regularly to measure and evaluate most of the PRPs and MDGs indicators.

\section{c. Employment Surveys}

Labor ministries use employment surveys to gather information on employment and wages. These surveys include questions about household income, demographics, and housing features. They can be good sources for employment statistics, income-based poverty indicators - if the income module is good - and input indicators such as access to basic services. Employment surveys tend to be more important information sources for heavily urbanized countries. Since the current trend of urbanization is quite alarming, there is an urgent need of imbibing the culture of conducting regularly this national survey.

\section{vi. National Account}

It is widely acknowledged that economic and social management of any nation need statistical information for measuring economic trends, levels of well-being and monitoring poverty, public finance balances, and external trade among others. To this end, the System of National Account 1993 (SNA1993) provides an organizing framework for compiling comprehensive economic accounts for Nigeria. 


\section{Macrothink Institute ${ }^{\mathrm{TM}}$}

The SNA93 is built on the fundamental concepts of macroeconomics and is designed for economic analysis and decision and policy making. This procedure is highly recommended by international organizations like WHO and IMF and now being implemented in all the ECOWAS member states including Nigeria.

\subsection{Dissemination Practices and Access Policy}

We advocate the following dissemination strategies for censuses and general routine surveys needed for proper implementation of the decentralized functional statistical system:

- Intense verbal communication (press briefings, electronic media, lunching of publications)

- Published results need to be widely disseminated (Presidency, State and National Parliaments, research institutions, public and universities libraries, media, stakeholders)

- The published data must be made available on CD-ROM, diskette

- Internet connectivity and Website providing or guiding on the mode of obtaining authorized information.

\section{Decision Support System}

The decision support system (DSS) is an organized collection of personnel, procedures, software, databases, and ICT devices working to support managerial decision making. DSS characteristics include the ability to

- handle large amounts of data;

- obtain and process data from different sources;

- provide report and presentation flexibility;

- $\quad$ support drill-down analysis;

- perform complex statistical analysis;

- offer textual and graphical orientations;

- and perform what if, simulation and goal seeking analysis..

We recommend the use of group support system for proper coordination and decision making of various sectors of NSS. A GSS is collaborative work system consists of most elements of DSS, plus software to provide effective support in group decision-making settings. GSS groupware software is especially designed to help generate lists of decision alternatives and perform data analysis. The system can easily integrate the System of National Account (SNA93) and the Suite Software Tools developed by the Global Office of the World Bank which is currently being recommended for routine usage by National Statistical Office (NSO), regional Coordinators (eg. ECOWAS), and the Global Office. The suite includes:

- ICP Tool Pack 


\section{Macrothink}

- Structured Product Description (SPD) Module

- Expenditure Weights Diagnostic Module(WDM)

- Ring Administration Module (RAM)

- Data Capture Forms(DCF)

- Equipment, construction and Compensation Data Validation Module(DVM)

\section{Conclusion}

We have conducted a comprehensive critic of the state of national statistics in the context of production and compilation of data, mining, depth of analysis, and dissemination of information on programmes of government and operations of private sector and non-governmental organisations. In all this, we have seen that the NSS as presently constituted is weak, fragmented and incomplete.

In short, the NSS lacks the capacity to deliver on its mandate of providing accurate, reliable and timely data that governments (that is, all the three tiers of government in Nigeria) need for evidence-based policy-formulation and decision-making. This state of affairs means that achievement of poverty reduction key MDG goal and other developmental goals of government may be seriously threatened. Nerveless, the National Bureau of Statistics (NBS) is still being reformed. The goal of the entire reform programme is to transform the NBS into a world class national statistical office.

Statistical capacity building in Nigeria should include development of statistics at the grassroots, that is, at the other two tiers of government, namely, state and local government. Hamadu and Okafor (2009) have given a blueprint about how this can be done with the establishment of state Bureau of Statistics. Ultimately, state and local area statistical systems when established should be integrated into the federal statistical system with the NBS as the coordinating agency. The present study also recommended the data collection and dissemination methodology for proper functioning of the NSS. Finally, the paradigm make used of GSS for comprehensive harmonised decision support system for states and federal sectoral statistical information needed for proper measuring, monitoring and evaluating progress of poverty and other developmental indicators.

\section{References}

Bonnen, J. (1988). 'Comment on Statistical Policy for State and Local Governments". The American Statistician vol. 42, No. 1, pp 16-18.

Bonnen, J. T., Clemence, T. G., Fellegi, I. P., Jabine, T.B., Kutscher, R. E., Roberson, L. K., and Waite, C. A. (1981). "Improving the Federal Statistical System: Report of the President's Reorganization Project for the Federal Statistical System." The American Statistician vol. 35, No. 4, pp 184-196. 


\section{Macrothink}

Duncan, J. W. (1988). 'Comment on Statistical Policy for State and Local Governments". The Am Statistician vol. 42, No. 1, pp 21-22.4.

Hamadu Dallah and Okafor Ray (2008), On Nigerian Statistical Building as a Panacea For Achieving Millennium Development Goals", $4^{\text {th }}$ Annual Research Conference Fair, University of Lagos, Lagos, Nigeria October, 2008.

Hamadu D and Okafor R (2009), On Statistical Capacity Building In Nigeria: A Necessary Step Towards Achieving Millennium Development Goals (MDGs), Statistical Journal of IAOS, 26, 21-32

Okafor, R. O. and Amaeshi, L. N. (2002). "On Grassroots Informatic in the Millennium: A Framework for Planning State and Local Government Statistics in Nigeria". Journal of Scientific Research and Development Vol. 7, pp. 55-68.

Kiregyera, B. (2001). " Novel Statistical Capacity Building Initiatives: Addis Ababa Plan of Action And Paris21" Invited paper presented at the 53rd Session of the International Statistical Institute, Seoul, Korea, 22-29 August, 2001.

National Planning Commission (2005), National Economic Empowerment and Development Strategy (NEEDS), Central Bank of Nigeria. Abuja, Nigeria, ISBN 0-9741108-4-1.

National Bureau of Statistics, Leaflet, NBS Secretariat Abuja 2007.

United Nations (2006), Governance for the Millenium Development Goals: Core Issues and Good Practices. United Nations Publication, ST/FSA/PAD/SER.E/99, New York. 